\title{
Transport of crustal microparticles from Chilean Patagonia to the Antarctic Peninsula by SEM-EDS analysis
}

\author{
By KELY CRISTINE DALIA PEREIRA ${ }^{1}$, HEITOR EVANGELISTA ${ }^{1 *}$, ENIO BUENO \\ PEREIRA ${ }^{2}$, JEFFERSON CARDIA SIMÕES ${ }^{3}$, ERLING JOHNSON ${ }^{4}$ and LETICIA \\ RODRIGUES MELO ${ }^{1}$, ${ }^{1}$ Laboratório de Radioecologia, LCR/DBB/IBRAG/Universidade do Estado do Rio de \\ Janeiro, Pavilhão Haroldo Lisboa da Cunha, Subsolo, Rua São Francisco Xavier 524, Maracanã, 20550-013 Rio de \\ Janeiro-RJ, Brazil; ${ }^{2}$ Instituto Nacional de Pesquisas Espaciais, Av. dos Astronautas 1758, Cx. Postal 515, 12201970 \\ São José dos Campos-SP, Brazil; ${ }^{3}$ Laboratório de Pesquisas Antárticas e Glaciológicas/Departamento de Geografia \\ Universidade Federal do Rio Grande do Sul, Av. Bento Gonçalves 9500, 91501-970 Porto Alegre-RS, Brazil; \\ ${ }^{4}$ Universidad Magallañes, Instituto de Fisica, Cassila 113-D, Punta Arenas, Chile
}

(Manuscript received 28 February 2003; in final form 4 February 2004)

\begin{abstract}
The individual elemental composition of insoluble airborne particulates found in King George Island (KGI), Antarctic Peninsula (atmosphere, snow, firn and ice deposits) and in the atmosphere of Chilean Patagonia by SEM-EDS analysis identify probable sources and transport mechanisms for the atmospheric aerosols observed in these regions. Insoluble airborne particulates found in the snow, firn and ice in a core from Lange Glacier (KGI) call for significant crustal influence, mainly associated with aluminium potassium, aluminium calcium and magnesium iron silicates together with other aluminium silicates of calcium and magnesium, among rare others containing $\mathrm{Ti}, \mathrm{Ni}$ and $\mathrm{Cr}$. Our study suggests that $95 \%$ of the bulk mode insoluble particulates deposited in Lange Glacier can be explained by atmospheric transport from Chilean Patagonia. Cyclonic systems passing between southernmost South America and the Antarctic Peninsula are the most probable atmospheric transport mechanism, tracked by measurements of ${ }^{222} \mathrm{Rn}$ and $\mathrm{Si}$.
\end{abstract}

\section{Introduction}

It is known that cyclones play an import role in the advective transport of atmospheric trace constituents, as well as heat, from the lower latitudes of South America to the northern limit of West Antarctica (Pereira, 1990; Evangelista, 1998). However, a better understanding of air-snow exchange and the deposition of particulate matter in ice and over ice-free areas, the probable origin of particles and association with mesoscale atmospheric circulation patterns is still required.

Pereira (1990), who has employed the terrigenous natural radioisotope ${ }^{222} \mathrm{Rn}$ as an atmospheric tracer in the Antarctic Peninsula for more than a decade, found a strong correlation among meteorological parameters (air temperature, atmospheric pressure and wind velocity), cyclone frequency and radon activity concentration in near-surface air. Moreover, Evangelista (1998) pointed out that the atmospheric transport efficiency during cy-

\footnotetext{
* Corresponding author.

e-mail: heitor@uerj.br
}

clone migration along the West Antarctica region is closely related to the trajectory and extension of the cyclonic system. Cyclone extension has to be large enough to produce a direct influence of the South American continent over the Antarctic Peninsula. Most cyclones that migrate between $50^{\circ} \mathrm{S}$ and $60^{\circ} \mathrm{S}$ have little influence over ${ }^{222} \mathrm{Rn}$ transport despite the fact that they control the surface wind velocity at King George Island (KGI). By contrast, most cyclones that migrate above $60^{\circ} \mathrm{S}$ travel through the southern tip of South America (Tierra del Fuego) and vanish in the South Atlantic Ocean or Weddell Sea, exerting an important influence over atmospheric transport to KGI. Figure 1 shows an event in which a cyclone branch moves polewards from South America to the Antarctic Peninsula yielding an increase in ${ }^{222} \mathrm{Rn}$ over KGI. The successful use of ${ }^{222} \mathrm{Rn}$ to describe the apportionment of air masses to the Antarctic is possible owing to its half-life (3.82 days), which is comparable to most tropospheric transport scales, to the development of highresolution, low-background real-time radon measurement techniques, to synoptic-scale air mass trajectory analysis (Chiminello et al. 2000) and to the development of validated numerical 

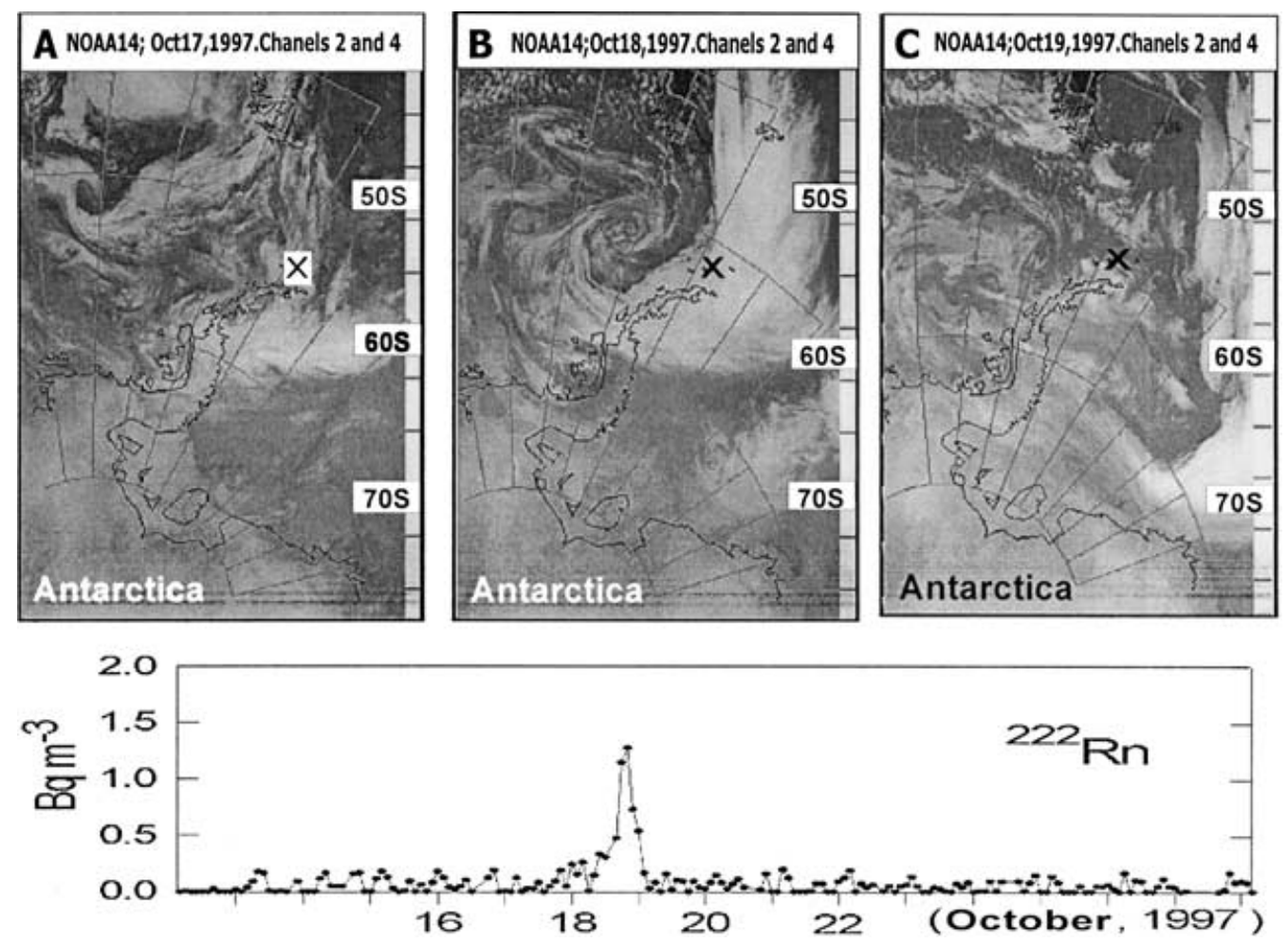

Fig 1. Eastward movement of a cyclonic system between South America and the Antarctic Peninsula with simultaneous increase of ${ }^{222} \mathrm{Rn}$ activity concentration. A, B and C indicate a 3-day satellite image acquisition at the Brazilian Antarctic Station. X marks the location of the sampling station.

models (Jacob et al. 1997). During the last decades, ${ }^{222} \mathrm{Rn}$ has been widely used in the Antarctic and sub-Antarctic regions as an atmospheric tracer of land continental air masses (Lambert et al. 1970; Schumann, 1972; Polian et al. 1986; Balkanski and Jacob, 1990). The reported radon production by the ocean surface, and the low emanation power of the ice-free areas in the South Shetlands/Antarctic Peninsula during austral summers, rule out these areas as important sources of radon (Evangelista and Pereira, 2002).

Atmospheric ${ }^{222} \mathrm{Rn}$ concentration activity increases simultaneously with the migration of the cyclone warm sector over KGI, demonstrating the impact of South American ice-free continental regions on the advective transport of air masses to Antarctica. However, our findings do not specify which part of the land is associated with this mechanism. Moreover, ${ }^{222} \mathrm{Rn}$ results cannot be extrapolated to atmospheric aerosols owing to the distinct behaviour of these two atmospheric trace components.

Correia (1998) presented a detailed study on seasonal variation of the elemental composition (coarse and fine modes) of aerosols in KGI employing particle-induced X-ray emission (PIXE) and multivariate statistics. This analysis grouped chemical elements having a probable common source (crustal, marine, anthropogenic or biogenic). Basile et al. (1997) studied the origin of airborne particles based on a comparison of stable isotope ratios of ${ }^{87} \mathrm{Sr} /{ }^{86} \mathrm{Sr}$ and ${ }^{143} \mathrm{Nd} /{ }^{144} \mathrm{Nd}$ in ice-trapped atmospheric particles in the Central Antarctic Plateau (Vostok and "Dome C"), and with surface soil and sediments of all continents surrounding Antarctica. They concluded that the Patagonian region (South America) was the most probable source of aerosols in East Antarctica. Iriondo (2000) proposed a climatic scenario to explain this process.

In contrast to the previous work, the present study investigates the similarities between the elemental composition of insoluble deposited particles found in an ice core from KGI and the airborne particles found in Chilean Patagonia and in the sea-level atmosphere of KGI. In addition, a simultaneous sampling of aerosols and ${ }^{222} \mathrm{Rn}$ was performed, together with satellite image acquisition, because of our better understanding of atmospheric transport from South America to the Antarctic Peninsula.

\section{Site description}

Atmospheric sampling and monitoring occurred at two sites: (1) KGI, at the Laboratory of Atmospheric Science, which is located $1700 \mathrm{~m}$ from the Brazilian Antarctic Station "Comandante Ferraz" $\left(62^{\circ} 05.0^{\prime} \mathrm{S}, 58^{\circ} 23.5^{\prime} \mathrm{W}\right)$, and (2) the campus of the Universidad de Magallañes located in the city of Punta Arenas $\left(53^{\circ} 10^{\prime} \mathrm{S}, 070^{\circ} 55^{\prime} \mathrm{W}\right)$, Chile. Ice coring took place at Lange Glacier (700 $\mathrm{m}$ above sea level) in KGI, $\left(62^{\circ} 07.8^{\prime} \mathrm{S}, 58^{\circ} 37.8^{\prime} \mathrm{W}\right)$. This island, part of the South Shetlands, is located about $1000 \mathrm{~km}$ 
from the southernmost part of South America, and about 100 $\mathrm{km}$ from the Antarctic Peninsula. The climate is predominantly polar-oceanic, characterized by low winter temperatures (annual average always below $0{ }^{\circ} \mathrm{C}$ ) and relatively mild summers with ice and snow melting exposing bare soils areas mostly along the coast, and high relative humidity and precipitation rates.

\section{Experimental methods}

\subsection{Atmospheric sampling and monitoring}

Sampling of airborne particles was achieved by continuous air filtration for 15-day integration time cycles at KGI from December 1996 to November 1997, and 30-day cycles for Chilean Patagonia from January to December 2000. Samplings at the two sites occurred at $15 \mathrm{~m}$ above the soil surface with typical airflow rate of 25 standard litres per minute, employing $47 \mathrm{~mm}$ quartz microfibre filters with a pore size of $0.45 \mu \mathrm{m}$.

\subsection{Sampling and handling of snow, firn and ice samples}

Samples were obtained from a $49.9 \mathrm{~m}$ core collected at the Lange Glacier during the austral summer of 1995 by the Brazilian glaciological team of Laboratório de Pesquisas Antárticas e Glaciológicas/Universidade Federal do Rio Grande do Sul. A conventional electrical-mechanical system was employed for ice drilling and core recovery. After correcting for density variations (depth given in metres of water equivalent $\left(\mathrm{meqH}_{2} \mathrm{O}\right)$ ), samples were divided into seven groups corresponding to shallow, intermediate and deep core sections in the following way: group $\mathrm{A}+\mathrm{B}$ equivalent to $0.5-1.04$ meq $_{2} \mathrm{O}$; group $\mathrm{C} 3.87-4.34$ meq $_{2} \mathrm{O}$; group D 7.25-8.25 meq $\mathrm{H}_{2} \mathrm{O}$; group E 13.85-14.84 meq $\mathrm{H}_{2} \mathrm{O}$; group F 23.0-24.01 meq $\mathrm{H}_{2} \mathrm{O}$; group $\mathrm{G}$ 26.01-26.98 meq $\mathrm{H}_{2} \mathrm{O}$; group $\mathrm{H} 30.70-31.25$ meq $_{2} \mathrm{O}$. Snow, firn and ice samples were melted in the laboratory, acidified with $0.3 \mathrm{ml}$ of $\mathrm{HNO}_{3} 60 \%$ and filtered with a $3.5 \mathrm{~cm}$ diameter cellulose acetate Millipore filter in an air-controlled closed circuit made of a peristaltic pump, a $100 \mathrm{ml}$ Dreschel flask containing melted ice samples and a filter holder apparatus.

\subsection{Elemental composition and mathematical analysis}

For each filter containing particles from air samplings or deposited insoluble particles in an ice-core section, a slice of onequarter of the effective sampling area was removed for the microanalysis method by scanning electron microscopy (model DSM960 Zeiss); microanalysis was made with an energy dispersive spectrometer (SEM-EDS) (Oxford Instruments SiLi-Be window). Spectrum resolution was $180 \mathrm{eV}$ for a $20 \mathrm{kV}$ beam energy. The resolution of the technique allows probing of elemental compositions in particle-equivalent diameters as low as $2 \mu \mathrm{m}$. Elemental composition was limited to $Z>10$, and data acquisition was automatically interrupted when total counts for the most abundant element reached 1000 or 2000 counts (40 to $120 \mathrm{~s}$ ). We have analysed a total of 180 predominantly insoluble airborne particles ( 58 for KGI, 43 for the Lange glacier and 80 for Chilean Patagonia). This technique required only very small numbers of collected particles, which made it useful for investigating short-term atmospheric transport events. This same technique was also applied to deep ice-core samples aiming at the characterization of aeolian continental dust trapped in the ice cap of the Antarctic Plateau (Brian et al. 1982; Petit et al. 1983). In our work, microphotographs and corresponding individual elemental compositions were obtained for predominant species of insoluble particles from the Lange ice core and airborne particles from KGI and Chilean Patagonia. Figure 2 shows the morphologies and elemental abundance of typical particles found at these three sites. They show evidence of $\mathrm{Na}$ and $\mathrm{Cl}$ enrichment for KGI; in samples from Chilean Patagonia the enrichment is for $\mathrm{Si}, \mathrm{Ca}, \mathrm{Al}, \mathrm{Fe}$, Ti and $\mathrm{K}$; and in the Lange ice core enrichment is for $\mathrm{Si}$. The insoluble particle database was obtained in the following way: after a complete optical scanning of the filter we selected the predominant particle structures considering the particle equivalent diameter and morphology. The period of air sampling at KGI was from December 1996 to November 1997. Identification of the particle types followed the definition $\Gamma \alpha$, where $\Gamma=1, \ldots, 12$ identifies the sequence of months and $\alpha=$ $a, \ldots, g$ specifies the predominant morphological structure. The same definition is valid for Chilean Patagonia with a sampling period from January 2000 to December 2000 with $\Gamma=1, \ldots$, 12 and $\alpha=a, \ldots, m$ because a larger variety of particles was detected. For the Lange Glacier, identification of predominant insoluble particles, $(\Gamma \alpha)$, was defined based on ice stratification. Therefore $\Gamma=A, B, \ldots, H$ and $\alpha=1, \ldots, 11$. For each species $\Gamma \alpha$ we performed elemental composition for $\mathrm{C}, \mathrm{O}, \mathrm{F}, \mathrm{Na}, \mathrm{Mg}$, $\mathrm{Al}, \mathrm{Si}, \mathrm{S}, \mathrm{Cl}, \mathrm{K}, \mathrm{Ca}, \mathrm{Ti}, \mathrm{Ba}, \mathrm{Cr}, \mathrm{Mn}, \mathrm{Fe}, \mathrm{Ni}$ and $\mathrm{Zn}$ and obtained their abundances. In a subsequent step we applied cluster analysis employing the "Single linkage" as the amalgamation (linkage) rule and the Euclidian distance. The goal was to group particle types according to their similarities in terms of elemental composition and abundance to investigate two main points: first, whether a group of particles occurs at an specific ice layer or in a specific period of the year, and second, to infer their most probable origin (crustal, marine or anthropogenic). Finally, taking the average composition of each element, a Pearson correlation was applied for the three sites.

\subsection{Correlation parameters}

We employed simultaneous monitoring of ${ }^{222} \mathrm{Rn}$ and aerosol samplings aiming at better identification of air masses and sources of trace elements. Radon was used to tag air masses according to the predominantly continental origin $\left({ }^{222} \mathrm{Rn}\right.$ enriched) or marine origin ( ${ }^{222} \mathrm{Rn}$ depleted). We employed a low-noise electrostatic precipitation chamber (Pereira and Evangelista, 1989) 


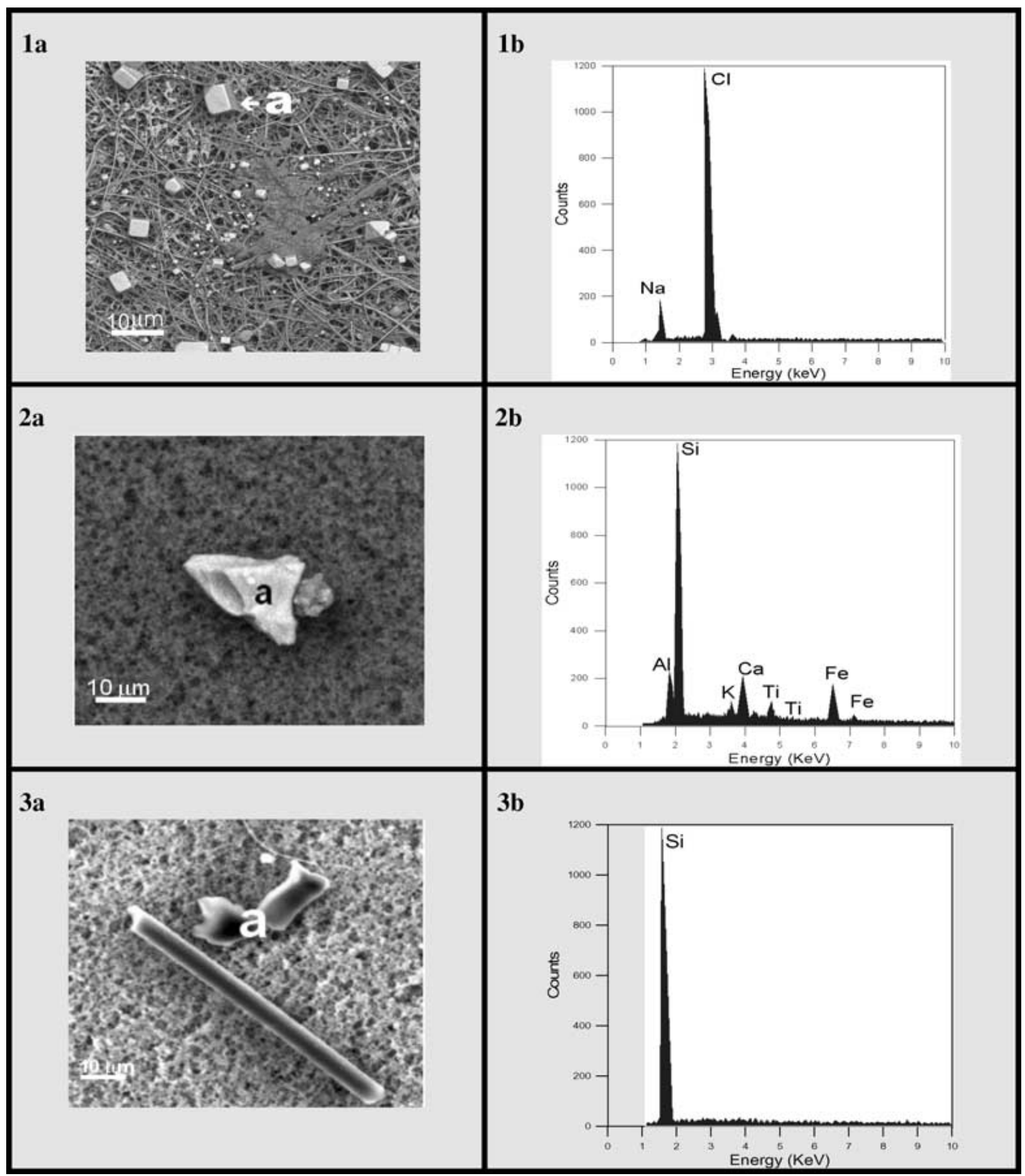

Fig 2. Morphology and corresponding spectrum of individual elemental composition for predominant insoluble particles in King George Island (1a and 1b), Chilean Patagonia ( $2 a$ and $2 b$ ) and the Lange Glacier ( $3 a$ and $3 b$ ). The "a" in the photographs indicates the electron target location.

to collect short-lived radon decay products and used real-time alpha spectrometry to measure the ${ }^{218} \mathrm{Po}$ and ${ }^{214} \mathrm{Po}$ to obtain the equivalent ${ }^{222} \mathrm{Rn}$ concentration activity in the air. Data acquisition took place every $2 \mathrm{~h}$ during continuous air sampling.
Daily acquisition of NOAA satellite images and synoptic charts during the sampling period was carried out to provide ancillary information on the atmospheric events favourable to aerosol transport. 


\section{Results and discussions}

\subsection{King George Island}

Cluster analysis applied to data from KGI, identified five clusters as shown in Table 1. Clusters 1 and 2 represent particles of predominantly marine origin. The first cluster, with predominance of $\mathrm{S}, \mathrm{O}$ and $\mathrm{Ca}$ (in this sequence), occurs systematically during the whole year. The second cluster is probably of marine/crustal origin as $\mathrm{Cl}, \mathrm{O}, \mathrm{Al}$ and $\mathrm{Fe}$ predominate. Cluster 3 corresponds to particles formed basically of quartz ( $\mathrm{Si}$ and $\mathrm{O}$ ); they occur mainly during the snow and ice melting season in KGI when rock outcrops and bare soils are abundant along the shoreline, although this can also occur to a lesser extent during winter. Cluster 4 represents particles of probable anthropogenic/biogenic source, with a strong predominance of carbon, usually associated with $\mathrm{Al}$ and $\mathrm{Cl}$. Aerosol type identification presented in Table 1 for cluster 4 indicates that it mostly occurs during the summer season (from November to February) — a similar behaviour is shown by black carbon aerosols in the Antarctic continent (Wolff and Cachier, 1998). This behaviour can be explained by the synoptic transport of air masses in the region (Murphey and Hogan, 1992) as well as by human activities at scientific stations in KGI (Evangelista, 1998) that maintain operation mostly during the austral summer. More recently, Dias da Cunha et al. (2004) employing a plasma desorption mass spectrometry (PDMS) technique in two samples of shallow snow cores $(5 \mathrm{~m}$ each) from a site near Lange Glacier detected insoluble carbon structures that can be attributed to an anthropogenic source, such as $\mathrm{VC}_{n}^{+}$and $\mathrm{CF}_{n}^{+}$; or a biogenic origin, such as $\mathrm{CH}_{3} \mathrm{NH}^{+} ; \mathrm{CH}_{2} \mathrm{CN}^{+} ; \mathrm{NH}_{4} \mathrm{CN}^{+}$; $\mathrm{C}_{n} \mathrm{H}_{m}^{+}$as $\mathrm{C}_{2} \mathrm{H}^{+}, \mathrm{C}_{2} \mathrm{H}_{2}^{+}, \mathrm{C}_{2} \mathrm{H}_{3}^{+}, \mathrm{C}_{2} \mathrm{H}_{5}^{+}, \mathrm{C}_{3} \mathrm{H}_{3}^{+}, \mathrm{C}_{3} \mathrm{H}_{5}^{+}, \mathrm{C}_{5}$ $\mathrm{H}^{+}, \mathrm{C}_{5} \mathrm{H}_{8}^{+}, \mathrm{C}_{6} \mathrm{H}_{5}^{+}, \mathrm{C}_{6} \mathrm{H}_{10}^{+}$and $\mathrm{C}_{7} \mathrm{H}_{3}^{+}$; and $\mathrm{C}_{n} \mathrm{H}_{m} \mathrm{O}^{+}$as $\mathrm{CH}_{3}$ $\mathrm{O}^{+}, \mathrm{C}_{3} \mathrm{H}_{7} \mathrm{O}^{+}$and $\mathrm{C}_{4} \mathrm{H}_{5} \mathrm{O}^{+}$. Carbon structures with Si enrichment were also found as $\left(\mathrm{CH}_{3}\right)_{2} \mathrm{SiH}^{+}$and $\left(\mathrm{CH}_{3}\right)_{5} \mathrm{Si}_{2} \mathrm{O}^{+}$. In addition, our data do not point unequivocally to a long-range atmospheric transport process. A more detailed study establishing a fingerprint of local aerosol production and long-range transport is still required. Cluster 5 represents the ocean influence of marine salt $(\mathrm{Cl}$ and $\mathrm{Na})$, systematically observed over the whole year.

\subsection{Chilean Patagonia (city of Punta Arenas)}

Table 2 shows the results for Chilean Patagonia. Five distinct groups of particles were also found. Cluster analysis revealed a high predominance of particles of marine and crustal origin occurring systematically throughout the year. Cluster 1 represents aerosols with $\mathrm{Cl}, \mathrm{Si}, \mathrm{S}, \mathrm{Na}$ and $\mathrm{Ca}$ enrichment, having mixed marine and marine/crustal origins. This cluster reveals two predominant sources for the aerosol in the Chilean Patagonia: soil dust resuspended by strong winds in this region, and polar-Pacific air masses whose trajectories pass through meridional Patagonia. Clusters 2, 4 and 5 also represent aerosols of crustal origin with predominance of $\mathrm{Si}, \mathrm{Al}, \mathrm{C}$, and $\mathrm{K}$ (in that sequence). Cluster 3 shows a predominance of $\mathrm{Fe}$ and $\mathrm{Si}$, and cluster 4 is characterized by aerosols enriched in $\mathrm{Ca}$ and in association with $\mathrm{Si}$ and $\mathrm{Fe}$. Cluster 5 is basically composed of $\mathrm{SiO}_{2}$ particles.

\subsection{Ice core from the Lange Glacier (King George Island)}

SEM-EDS microanalysis showed a large variability of insoluble particles in terms of morphology and elemental composition in strata from the Lange ice core. The cluster analysis was applied to ice-core data to investigate whether any specific group of deposited particles occurs preferentially at a certain depth interval or if occurrence was homogenous along the successive layers. This would provide important key information about changes in atmospheric transport and depositional regimes associated with global-scale events or on a regional scale. Table 3 presents the identification by type and the corresponding elemental composition.

Cluster analysis for insoluble particles in snow, firn and ice samples also exhibits five distinct groups: clusters 1, 2, 4 and 5 represent particles of predominantly crustal origin, the first group has a predominance of $\mathrm{Si}, \mathrm{Fe}$ and $\mathrm{Al}$ (in that sequence) that are observed systematically along the ice core associated with $\mathrm{Cr}, \mathrm{Ni}, \mathrm{Mg}$ and $\mathrm{Zn}$ in minor proportions (average below $1 \%$ ). Cluster 2 shows a predominance of metallic components such as Fe and Cr. Cluster 3 shows insoluble particles, probably of marine/crustal origin and with predominance of $\mathrm{S}, \mathrm{Cl}$ and $\mathrm{Si}$. Cluster 4 is basically $\mathrm{SiO}_{2}$ and cluster 5 is related to particles enriched in $\mathrm{Al}, \mathrm{S}$ and $\mathrm{Si}$ occurring only below $23 \mathrm{meqH}_{2} \mathrm{O}$, and with equivalent diameters in the range of 20-70 $\mu \mathrm{m}$.

\subsection{Equivalent diameters of deposited insoluble particles in the Lange ice core}

Figure 3 shows extreme values of equivalent diameters of insoluble particles found in the Lange ice core compared with the maximum values observed from 1-yr aerosol monitoring in KGI and Chilean Patagonia. From this granulometric approach it can be inferred that all insoluble particles from Lange presenting diameters below the maximum value observed for KGI could be explained by local contribution such as marine spray, resuspension due aeolian processes on bare soils and rock outcrops, and by anthropogenic activities from scientific stations located in the island a total of nine). Insoluble particle species indicated in Fig. 4 by $1,6,7,8,10$ and 11 have diameters not statistically different from the maximum size found during atmospheric monitoring at KGI, if we consider the uncertainties of the method. Particle species indicated by 3, 4 and 5 all belong to the ice layer " $F$ ", dated to the end the 1940s. A possible explanation for the presence of these coarse particles (species 4 presented at $170 \mu \mathrm{m}$ ) in the Lange Glacier can be related to active vulcanism on the South Shetlands or the effect of atmospheric transport followed 
Table 1. Cluster analysis for elemental composition of particles collected at King George Island

\begin{tabular}{|c|c|c|}
\hline Type & Elemental composition & Average proportion $(>1 \%)$ \\
\hline \multicolumn{3}{|c|}{ CLUSTER 1} \\
\hline $1 b$ & $\mathrm{~S}, \mathrm{Ca}, \mathrm{O}, \mathrm{Na}$ & $\mathrm{S}=42.06$ \\
\hline $1 \mathrm{c}$ & $\mathrm{S}, \mathrm{O}, \mathrm{Mg}, \mathrm{Na}$ & $\mathrm{O}=22.53$ \\
\hline $1 d$ & $\mathrm{~S}, \mathrm{O}, \mathrm{Cl}, \mathrm{Mg}, \mathrm{Si}, \mathrm{Na}, \mathrm{K}$ & $\mathrm{Ca}=13.12$ \\
\hline $2 \mathrm{~d}$ & $\mathrm{~S}, \mathrm{O}, \mathrm{Ca}, \mathrm{K}, \mathrm{Mg}, \mathrm{Cl}$ & $\mathrm{Mg}=6.29$ \\
\hline $4 b$ & $\mathrm{~S}, \mathrm{Cl}, \mathrm{O}, \mathrm{K}, \mathrm{Ca}, \mathrm{Mg}, \mathrm{C}, \mathrm{Al}$ & $\mathrm{Cl}=5.18$ \\
\hline $4 \mathrm{e}$ & $\mathrm{S}, \mathrm{Ca}, \mathrm{K}, \mathrm{O}, \mathrm{Cl}, \mathrm{Mg}$ & $\mathrm{K}=3.88$ \\
\hline $6 \mathrm{~d}$ & $\mathrm{~S}, \mathrm{O}, \mathrm{Mg}, \mathrm{Na}$ & $\mathrm{Ba}=2.94$ \\
\hline $7 b$ & $\mathrm{~S}, \mathrm{O}, \mathrm{Mg}, \mathrm{Na}$ & $\mathrm{Na}=1.82$ \\
\hline $7 d$ & $\mathrm{~S}, \mathrm{Ca}, \mathrm{O}, \mathrm{Si}$ & $\mathrm{Si}=1.06$ \\
\hline $8 b$ & $\mathrm{~S}, \mathrm{O}, \mathrm{Mg}, \mathrm{Na}$ & \\
\hline $9 b$ & $\mathrm{Ca}, \mathrm{S}, \mathrm{O}, \mathrm{Si}, \mathrm{Cl}$ & \\
\hline $10 \mathrm{a}$ & $\mathrm{Ba}, \mathrm{S}, \mathrm{O}, \mathrm{Cl}, \mathrm{K}, \mathrm{Ca}, \mathrm{Si}, \mathrm{Mg}$ & \\
\hline $10 \mathrm{~b}$ & $\mathrm{~S}, \mathrm{Ca}, \mathrm{K}, \mathrm{O}, \mathrm{Cl}, \mathrm{Mg}, \mathrm{Si}$ & \\
\hline $12 b$ & $\mathrm{Ca}, \mathrm{S}, \mathrm{O}, \mathrm{Si}, \mathrm{Cl}$ & \\
\hline $12 \mathrm{c}$ & $\mathrm{S}, \mathrm{O}, \mathrm{Mg}, \mathrm{Cl}$ & \\
\hline $12 \mathrm{~g}$ & $\mathrm{~S}, \mathrm{O}, \mathrm{Fe}, \mathrm{Cl}, \mathrm{Mg}, \mathrm{K}, \mathrm{Cr}, \mathrm{Ni}$ & \\
\hline \multicolumn{3}{|c|}{ CLUSTER 2} \\
\hline $2 \mathrm{c}$ & $\mathrm{Cl}, \mathrm{O}, \mathrm{Si}, \mathrm{S}, \mathrm{Fe}, \mathrm{Al}, \mathrm{K}, \mathrm{Na}, \mathrm{Mg}$ & $\mathrm{Cl}=21.0$ \\
\hline $4 a$ & $\mathrm{C}, \mathrm{O}, \mathrm{Al}, \mathrm{Cl}, \mathrm{Mg}, \mathrm{S}, \mathrm{K}, \mathrm{Si}, \mathrm{Ca}$ & $\mathrm{O}=21.0$ \\
\hline $4 d$ & $\mathrm{O}, \mathrm{Cl}, \mathrm{Fe}, \mathrm{Si}, \mathrm{S}, \mathrm{Cr}, \mathrm{Mg}, \mathrm{K}, \mathrm{Al}, \mathrm{Ca}$ & $\mathrm{Al}=16.0$ \\
\hline $5 \mathrm{c}$ & $\mathrm{O}, \mathrm{Al}, \mathrm{Cl}, \mathrm{S}$ & $\mathrm{Fe}=13.73$ \\
\hline $5 e$ & $\mathrm{Fe}, \mathrm{Cl}, \mathrm{Si}, \mathrm{O}, \mathrm{Al}, \mathrm{Mg}, \mathrm{Mn}, \mathrm{S}, \mathrm{K}$ & $\mathrm{S}=7.09$ \\
\hline $6 \mathrm{a}$ & $\mathrm{O}, \mathrm{Fe}, \mathrm{Cl}, \mathrm{Al}, \mathrm{Mg}, \mathrm{S}$ & $\mathrm{C}=5.91$ \\
\hline $8 \mathrm{a}$ & $\mathrm{Cl}, \mathrm{Al}, \mathrm{C}, \mathrm{Si}, \mathrm{O}, \mathrm{S}$ & $\mathrm{Si}=5.55$ \\
\hline $10 \mathrm{~d}$ & $\mathrm{Cl}, \mathrm{Al}, \mathrm{C}, \mathrm{O}, \mathrm{S}, \mathrm{Si}$ & $\mathrm{Cr}=2.73$ \\
\hline $11 \mathrm{a}$ & $\mathrm{Al}, \mathrm{O}, \mathrm{Cl}, \mathrm{S}, \mathrm{K}$ & $K=2.36$ \\
\hline $12 \mathrm{~d}$ & $\mathrm{Fe}, \mathrm{Cr}, \mathrm{S}, \mathrm{Ca}, \mathrm{O}, \mathrm{Cl}, \mathrm{Si}, \mathrm{K}$ & $\mathrm{Mg}=2.18$ \\
\hline $12 \mathrm{f}$ & $\mathrm{Cl}, \mathrm{O}, \mathrm{S}, \mathrm{Si}, \mathrm{K}, \mathrm{Mg}, \mathrm{Ca}, \mathrm{Al}, \mathrm{Ti}, \mathrm{Na}, \mathrm{Zn}$ & \\
\hline \multicolumn{3}{|c|}{ CLUSTER 3} \\
\hline $2 b$ & $\mathrm{Si}, \mathrm{O}, \mathrm{Al}, \mathrm{K}, \mathrm{Ca}, \mathrm{Fe}, \mathrm{Na}, \mathrm{Ti}$ & $\mathrm{Si}=37.5$ \\
\hline $3 \mathrm{a}$ & $\mathrm{Si}, \mathrm{O}, \mathrm{C}, \mathrm{Cl}, \mathrm{K}, \mathrm{Al}, \mathrm{Na}, \mathrm{Ca}, \mathrm{Ba}, \mathrm{Fe}, \mathrm{Zn}$ & $O=18.6$ \\
\hline $3 \mathrm{c}$ & $\mathrm{Si}, \mathrm{O}, \mathrm{Ca}, \mathrm{Ti}, \mathrm{Mg}, \mathrm{Al}, \mathrm{S}, \mathrm{K}, \mathrm{Cl}$ & $\mathrm{Al}=9.1$ \\
\hline $3 \mathrm{~d}$ & $\mathrm{Si}, \mathrm{O}, \mathrm{Al}, \mathrm{K}, \mathrm{S}, \mathrm{Fe}, \mathrm{Cl}$ & $\mathrm{Cl}=8.2$ \\
\hline $4 c$ & $\mathrm{Si}, \mathrm{O}, \mathrm{Al}, \mathrm{Ca}, \mathrm{Fe}, \mathrm{Na}, \mathrm{Mg}, \mathrm{S}, \mathrm{Cl}, \mathrm{K}, \mathrm{Ti}$ & $\mathrm{Ca}=6.7$ \\
\hline $7 \mathrm{a}$ & $\mathrm{Si}, \mathrm{O}, \mathrm{C}, \mathrm{K}, \mathrm{Ba}, \mathrm{Al}, \mathrm{Ca}, \mathrm{F}, \mathrm{Na}, \mathrm{Cl}, \mathrm{Zn}$ & $\mathrm{K}=4.4$ \\
\hline $9 \mathrm{a}$ & $\mathrm{Si}, \mathrm{Cl}, \mathrm{Al}, \mathrm{O}, \mathrm{S}, \mathrm{K}, \mathrm{C}, \mathrm{Mg}, \mathrm{Ca}, \mathrm{Ti}, \mathrm{Fe}$ & $\mathrm{S}=3.4$ \\
\hline $9 \mathrm{~d}$ & $\mathrm{Si}, \mathrm{O}, \mathrm{Ca}, \mathrm{Al}, \mathrm{Fe}, \mathrm{Ti}, \mathrm{S}, \mathrm{Cl}, \mathrm{K}$ & $\mathrm{Fe}=3.1$ \\
\hline $10 \mathrm{c}$ & $\mathrm{Cl}, \mathrm{Si}, \mathrm{O}, \mathrm{S}, \mathrm{K}, \mathrm{Ca}, \mathrm{Al}, \mathrm{Ti}, \mathrm{C}, \mathrm{Zn}$ & $\mathrm{C}=2.2$ \\
\hline \multirow[t]{3}{*}{$12 \mathrm{e}$} & $\mathrm{Si}, \mathrm{O}, \mathrm{Ca}, \mathrm{Al}, \mathrm{S}, \mathrm{Cl}, \mathrm{K}, \mathrm{Fe}$ & $\mathrm{Ti}=2.1$ \\
\hline & & $\mathrm{Mg}=1.1$ \\
\hline & & $\mathrm{Na}=1$ \\
\hline \multicolumn{3}{|c|}{ CLUSTER 4} \\
\hline $1 \mathrm{a}$ & $\mathrm{C}, \mathrm{Al}, \mathrm{O}, \mathrm{S}, \mathrm{Cl}$ & $\mathrm{C}=70$ \\
\hline $2 \mathrm{a}$ & $\mathrm{C}$ & $\mathrm{Al}=14$ \\
\hline $3 b$ & $\mathrm{C}, \mathrm{Al}, \mathrm{Cl}, \mathrm{O}, \mathrm{S}$ & $\mathrm{O}=7.2$ \\
\hline $5 \mathrm{~d}$ & $\mathrm{C}, \mathrm{Al}, \mathrm{O}, \mathrm{Si}, \mathrm{S}, \mathrm{Cl}$ & $\mathrm{Cl}=5.6$ \\
\hline $11 \mathrm{c}$ & $\mathrm{C}, \mathrm{O}, \mathrm{Al}, \mathrm{Cl}$ & $\mathrm{S}=2.6$ \\
\hline \multicolumn{3}{|c|}{ CLUSTER 5} \\
\hline $1 \mathrm{e}$ & $\mathrm{Cl}, \mathrm{Na}$ & $\mathrm{Cl}=78.0$ \\
\hline $2 \mathrm{e}$ & $\mathrm{Cl}, \mathrm{Na}$ & $\mathrm{Na}=12.33$ \\
\hline $3 e$ & $\mathrm{Cl}, \mathrm{Na}$ & $\mathrm{K}=2.8$ \\
\hline $4 \mathrm{f}$ & $\mathrm{Cl}, \mathrm{Na}$ & $\mathrm{Mg}=2.47$ \\
\hline
\end{tabular}


Table 1. (cont'd).

\begin{tabular}{|c|c|c|}
\hline Type & Elemental composition & Average proportion $(>1 \%)$ \\
\hline $5 \mathrm{a}$ & $\mathrm{Cl}, \mathrm{O}, \mathrm{Mg}, \mathrm{S}$ & $\mathrm{O}=2.07$ \\
\hline $5 b$ & $\mathrm{Cl}, \mathrm{K}, \mathrm{Mg}, \mathrm{O}$ & $\mathrm{Al}=1.33$ \\
\hline $5 f$ & $\mathrm{Cl}, \mathrm{Na}$ & $\mathrm{S}=1$ \\
\hline $6 \mathrm{~b}$ & $\mathrm{Cl}, \mathrm{K}, \mathrm{Mg}, \mathrm{Al}, \mathrm{O}, \mathrm{S}$ & \\
\hline $6 c$ & $\mathrm{Cl}, \mathrm{Na}$ & \\
\hline $7 \mathrm{c}$ & $\mathrm{Cl}, \mathrm{Na}$ & \\
\hline $8 \mathrm{c}$ & $\mathrm{Cl}, \mathrm{Na}$ & \\
\hline $9 \mathrm{c}$ & $\mathrm{S}, \mathrm{O}, \mathrm{Mg}$ & \\
\hline $10 \mathrm{e}$ & $\mathrm{Cl}, \mathrm{Na}$ & \\
\hline $11 \mathrm{~b}$ & $\mathrm{Cl}, \mathrm{Al}, \mathrm{Si}, \mathrm{K}, \mathrm{O}, \mathrm{Mg}$ & \\
\hline $11 d$ & $\mathrm{Cl}, \mathrm{Na}$ & \\
\hline $12 \mathrm{a}$ & $\mathrm{Cl}, \mathrm{Na}$ & \\
\hline
\end{tabular}

by strong winds in the region. The particle species cited above (3, 4 and 5) corresponded to the "F1" particle which is purely $\mathrm{AlO}$, "F3", which is purely $\mathrm{SiO}_{2}$, and "F7", a typical particle of crustal origin having $\mathrm{Si}, \mathrm{O}, \mathrm{Al}, \mathrm{Fe}, \mathrm{Cl}, \mathrm{S}, \mathrm{Ca}, \mathrm{K}$, Ti and $\mathrm{Zn}$ in its composition. Insoluble particle species indicated by 2, 9 and 12 occurred in different ice layers and are also of crustal origin with a predominance of $\mathrm{Si}$ (quartz and an association of $\mathrm{Si}, \mathrm{Ca}$, $\mathrm{O}, \mathrm{Al}$ and $\mathrm{K}$ ). Despite the fact that these particles, of size larger than $50 \mu \mathrm{m}$, were not observed during atmospheric monitoring in KGI, they are evidences of past climate, of apportionment of mineral particles associated to wind regimes of high intensity.

\subsection{Comparison of relative elemental abundance of atmospheric aerosols with insoluble particles found in snow, firn and in ice samples}

The determination of the individual elemental composition of predominantly coarse mode insoluble airborne particles by the same method, SEM-EDS, from an ice core (Lange Glacier) and from air filters (KGI and Chilean Patagonia) make possible a direct comparison of the results. Figure 4 shows a histogram of elemental relative abundance for all particles measured in this work as described above.

The Pearson correlation coefficient, $r$, between insoluble particles of the Lange Glacier and Chilean Patagonia was obtained from the linear regression of average values of relative abundance for each element, considering all particle types as defined in Section 3.3. In this case we found $r=0.95$. This result represents a high similarity level for elemental composition between particles deposited in the Lange Glacier and the airborne particles found in the atmosphere of Chilean Patagonia, even considering the different time periods and taking into account only coarse-mode particles. This reinforces the idea that suspended particles over Chilean Patagonia (or a geological equivalent regional extent over meridional South America as was postulated by Iriondo 2000) would be the source of the majority of coarsemode particles deposited in West Antarctica. In contrast, there is no statistically significant correlation between insoluble airborne particles in the KGI atmosphere and particles deposited in the Lange Glacier, $r=0.25$ ( $p<0.05$ ). Artaxo et al. (1990) have demonstrated, by using electron probe microanalysis (EPMA), that soil dust from ice-free areas of KGI makes up only $3 \%$ of the total suspended coarse-mode particles ( $97 \%$ was of marine origin) and, therefore, we conclude that the contribution of additional particles from local ice-free areas during summer time, is not relevant to the total number of particles deposited in the Lange Glacier.

\subsection{Si-enriched insoluble particles}

Si-enriched insoluble particles are by far the most abundant ones found in shallow, intermediate and deep layers of the Lange Glacier. Si was the only element of non-marine origin found in significant concentration in all the ice strata examined. A comparison of the relative elemental abundance is shown in Table 4.

In order to investigate a possible atmospheric transport mechanism involving apportionment of Si-enriched aerosols to the Antarctic Peninsula, we performed continuous air monitoring and simultaneous atmospheric ${ }^{222} \mathrm{Rn}$ activity concentration measurements (the ${ }^{222} \mathrm{Rn}$ being employed as an atmospheric tracer) at the Brazilian Antarctic Station. In situ acquisition of satellite images and synoptic charts were used to identify air mass trajectories and low atmospheric pressure displacement. Sanak (1989), Lambert et al. (1990), and Pereira (1990) demonstrated that surges of the ${ }^{222} \mathrm{Rn}$ for the outer limits of Antarctica (called a "radon storm") were associated with air mass trajectories and past transit over continental land areas. Figure 5 shows results of the ${ }^{222} \mathrm{Rn}$ monitoring and $\mathrm{Si}$ abundance in air filters. During the observation period a pronounced increase in activity ${ }^{222} \mathrm{Rn}$ concentration occurred in June, followed by the largest annual increase of Si. Neither event can be explained by local production since they took place during winter when snow accumulation is large enough to hinder gas emanation and fine dust resuspension. 
Table 2. Cluster analysis for elemental composition of particles collected in Chilean Patagonia

\begin{tabular}{|c|c|c|}
\hline Type & Elemental composition & Average proportion $(>1 \%)$ \\
\hline \multicolumn{3}{|c|}{ CLUSTER 1} \\
\hline $1 \mathrm{e}$ & $\mathrm{Cl}, \mathrm{Si}, \mathrm{O}$ & $\mathrm{Cl}=55$ \\
\hline $2 \mathrm{c}$ & $\mathrm{Si}, \mathrm{Cl}, \mathrm{Na}, \mathrm{O}$ & $\mathrm{Si}=16.54$ \\
\hline $2 \mathrm{~g}$ & $\mathrm{Cl}, \mathrm{S}, \mathrm{Ca}, \mathrm{O}, \mathrm{Si}, \mathrm{K}$ & $\mathrm{O}=7.38$ \\
\hline $3 \mathrm{~h}$ & $\mathrm{~S}, \mathrm{Cl}, \mathrm{Ca}, \mathrm{O}$ & $\mathrm{S}=6.54$ \\
\hline $4 \mathrm{e}$ & $\mathrm{Cl}, \mathrm{Si}, \mathrm{O}$ & $\mathrm{Na}=5.77$ \\
\hline $5 \mathrm{a}$ & $\mathrm{Cl}, \mathrm{Na}$ & $\mathrm{Ca}=3.61$ \\
\hline $5 b$ & $\mathrm{Cl}, \mathrm{S}, \mathrm{O}, \mathrm{Si}, \mathrm{K}, \mathrm{Ca}$ & $K=2.54$ \\
\hline $7 d$ & $\mathrm{Cl}, \mathrm{Si}, \mathrm{O}, \mathrm{K}, \mathrm{Al}, \mathrm{Ca}, \mathrm{Ba}$ & $\mathrm{Al}=1.31$ \\
\hline $9 \mathrm{a}$ & $\mathrm{Cl}, \mathrm{Si}, \mathrm{Al}, \mathrm{O}, \mathrm{K}, \mathrm{Ca}$ & $\mathrm{Ba}=1.31$ \\
\hline $9 \mathrm{e}$ & $\mathrm{Cl}, \mathrm{Na}$ & \\
\hline $11 \mathrm{c}$ & $\mathrm{Cl}, \mathrm{Na}$ & \\
\hline $11 d$ & $\mathrm{Cl}, \mathrm{Si}, \mathrm{O}$ & \\
\hline $12 b$ & $\mathrm{Cl}, \mathrm{Si}, \mathrm{Ba}, \mathrm{O}$ & \\
\hline \multicolumn{3}{|c|}{ CLUSTER 2} \\
\hline $1 \mathrm{a}$ & $\mathrm{Si}, \mathrm{O}, \mathrm{Al}, \mathrm{Ca}, \mathrm{Fe}, \mathrm{K}, \mathrm{Ti}$ & $\mathrm{Si}=31.62$ \\
\hline $1 \mathrm{c}$ & $\mathrm{Si}, \mathrm{O}, \mathrm{Al}, \mathrm{Cl}, \mathrm{Fe}$ & $\mathrm{O}=20.46$ \\
\hline $1 d$ & $\mathrm{Si}, \mathrm{O}, \mathrm{Al}, \mathrm{Cl}, \mathrm{K}, \mathrm{Ca}, \mathrm{Fe}$ & $\mathrm{Al}=12.13$ \\
\hline $2 b$ & $\mathrm{~S}, \mathrm{Si}, \mathrm{O}, \mathrm{Ca}, \mathrm{Ti}, \mathrm{K}, \mathrm{Al}, \mathrm{Cl}, \mathrm{Fe}$ & $\mathrm{K}=8.62$ \\
\hline $2 \mathrm{e}$ & $\mathrm{Si}, \mathrm{O}, \mathrm{Al}, \mathrm{K}, \mathrm{Fe}$ & $\mathrm{Ca}=7.24$ \\
\hline $2 \mathrm{f}$ & $\mathrm{Si}, \mathrm{O}, \mathrm{Al}, \mathrm{Ca}, \mathrm{Fe}$ & $\mathrm{Cl}=6.84$ \\
\hline $2 \mathrm{~h}$ & $\mathrm{Si}, \mathrm{O}, \mathrm{Al}, \mathrm{Cl}, \mathrm{Ca}, \mathrm{Fe}$ & $\mathrm{Fe}=3.62$ \\
\hline $2 \mathrm{i}$ & $\mathrm{Si}, \mathrm{O}, \mathrm{Al}, \mathrm{K}, \mathrm{Cl}$ & $\mathrm{S}=3.08$ \\
\hline $2 \mathrm{j}$ & $\mathrm{Si}, \mathrm{O}, \mathrm{Al}, \mathrm{K}$ & $\mathrm{Ti}=2.70$ \\
\hline 21 & $\mathrm{Si}, \mathrm{O}, \mathrm{Al}, \mathrm{K}, \mathrm{Ca}, \mathrm{Fe}, \mathrm{S}, \mathrm{Cl}$ & \\
\hline $2 \mathrm{~m}$ & $\mathrm{Si}, \mathrm{O}, \mathrm{Al}, \mathrm{K}, \mathrm{Ca}, \mathrm{S}$ & \\
\hline $3 \mathrm{a}$ & $\mathrm{Si}, \mathrm{O}, \mathrm{Al}, \mathrm{Cl}, \mathrm{K}, \mathrm{Ca}$ & \\
\hline $3 b$ & $\mathrm{Si}, \mathrm{Cl}, \mathrm{O}, \mathrm{S}, \mathrm{K}, \mathrm{Ca}, \mathrm{Ti}$ & \\
\hline $3 \mathrm{e}$ & $\mathrm{Si}, \mathrm{Cl}, \mathrm{O}$ & \\
\hline $3 f$ & $\mathrm{Si}, \mathrm{O}, \mathrm{Al}, \mathrm{Ca}, \mathrm{Fe}$ & \\
\hline $4 a$ & $\mathrm{~K}, \mathrm{~S}, \mathrm{O}, \mathrm{Cl}, \mathrm{Si}, \mathrm{Ca}$ & \\
\hline $4 \mathrm{c}$ & $\mathrm{O}, \mathrm{Cl}, \mathrm{Si}, \mathrm{S}, \mathrm{P}, \mathrm{K}, \mathrm{Ca}, \mathrm{Al}, \mathrm{Ti}, \mathrm{Fe}, \mathrm{Zn}$ & \\
\hline $4 d$ & $\mathrm{O}, \mathrm{Cl}, \mathrm{K}, \mathrm{Si}$ & \\
\hline $4 g$ & $\mathrm{Si}, \mathrm{O}, \mathrm{K}, \mathrm{Ca}, \mathrm{Cl}, \mathrm{Ti}, \mathrm{Zn}$ & \\
\hline $5 \mathrm{~d}$ & $\mathrm{Si}, \mathrm{O}, \mathrm{K}, \mathrm{Al}, \mathrm{Fe}$ & \\
\hline $5 \mathrm{e}$ & $\mathrm{Si}, \mathrm{O}, \mathrm{Ca}, \mathrm{S}, \mathrm{K}, \mathrm{Cl}$ & \\
\hline $6 c$ & $\mathrm{Si}, \mathrm{O}, \mathrm{Cl}, \mathrm{S}, \mathrm{K}, \mathrm{Ca}, \mathrm{Al}, \mathrm{Ti}, \mathrm{Zn}$ & \\
\hline $6 e$ & $\mathrm{Cu}, \mathrm{Si}, \mathrm{O}, \mathrm{k}, \mathrm{Al}, \mathrm{Ca}, \mathrm{Ti}$ & \\
\hline $6 g$ & $\mathrm{Si}, \mathrm{O}, \mathrm{Al}, \mathrm{k}, \mathrm{Fe}, \mathrm{Cl}, \mathrm{Ca}$ & \\
\hline $7 b$ & $\mathrm{Si}, \mathrm{O}, \mathrm{Al}, \mathrm{K}$ & \\
\hline $7 \mathrm{c}$ & $\mathrm{Si}, \mathrm{O}, \mathrm{Al}, \mathrm{Fe}$ & \\
\hline $8 b$ & $\mathrm{Si}, \mathrm{Ca}, \mathrm{O}, \mathrm{Al}, \mathrm{Fe}$ & \\
\hline $8 c$ & $\mathrm{Si}, \mathrm{Ca}, \mathrm{O}, \mathrm{Cl}, \mathrm{K}, \mathrm{Fe}, \mathrm{Al}, \mathrm{S}, \mathrm{Ti}$ & \\
\hline $8 \mathrm{~d}$ & $\mathrm{Al}, \mathrm{Si}, \mathrm{O}, \mathrm{Cl}, \mathrm{K}$ & \\
\hline $8 \mathrm{e}$ & $\mathrm{Si}, \mathrm{Ca}, \mathrm{O}, \mathrm{Al}$ & \\
\hline $9 \mathrm{~d}$ & $\mathrm{Ti}, \mathrm{O}, \mathrm{Si}, \mathrm{Cl}, \mathrm{Ca}, \mathrm{Al}$ & \\
\hline $10 \mathrm{a}$ & $\mathrm{Si}, \mathrm{O}, \mathrm{Al}, \mathrm{K}, \mathrm{Fe}$ & \\
\hline $11 \mathrm{a}$ & $\mathrm{Al}, \mathrm{Si}, \mathrm{K}, \mathrm{O}, \mathrm{Ca}$ & \\
\hline $11 b$ & $\mathrm{Al}, \mathrm{Si}, \mathrm{O}, \mathrm{Fe}, \mathrm{K}, \mathrm{Ca}$ & \\
\hline $11 \mathrm{~h}$ & $\mathrm{~Pb}, \mathrm{Ba}, \mathrm{O}, \mathrm{Si}, \mathrm{K}, \mathrm{Al}, \mathrm{Ca}$ & \\
\hline $12 \mathrm{a}$ & $\mathrm{Si}, \mathrm{O}, \mathrm{Al}, \mathrm{Ca}, \mathrm{K}, \mathrm{Fe}$ & \\
\hline $12 \mathrm{~d}$ & $\mathrm{Si}, \mathrm{O}, \mathrm{Cl}, \mathrm{Al}, \mathrm{K}, \mathrm{Ca}, \mathrm{Fe}, \mathrm{S}, \mathrm{Ti}$ & \\
\hline
\end{tabular}


Table 2. (cont'd).

\begin{tabular}{|c|c|c|}
\hline Type & Elemental composition & Average proportion $(>1 \%)$ \\
\hline \multicolumn{3}{|c|}{ CLUSTER 3} \\
\hline $1 b$ & $\mathrm{Fe}, \mathrm{Si}, \mathrm{O}$ & $\mathrm{Fe}=41$ \\
\hline $2 \mathrm{a}$ & $\mathrm{Fe}, \mathrm{Si}, \mathrm{Al}, \mathrm{K}, \mathrm{Ca}, \mathrm{O}, \mathrm{Ti}$ & $\mathrm{Si}=33$ \\
\hline $3 \mathrm{c}$ & $\mathrm{Fe}, \mathrm{Si}, \mathrm{O}$ & $\mathrm{O}=12.53$ \\
\hline $3 i$ & $\mathrm{Fe}, \mathrm{Si}, \mathrm{Al}, \mathrm{K}, \mathrm{O}, \mathrm{Ti}, \mathrm{Ca}$ & $\mathrm{Al}=4.13$ \\
\hline $4 b$ & $\mathrm{Fe}, \mathrm{Si}, \mathrm{Al}, \mathrm{K}, \mathrm{O}, \mathrm{Ti}, \mathrm{Ca}$ & $\mathrm{K}=3.87$ \\
\hline $4 \mathrm{f}$ & $\mathrm{Fe}, \mathrm{Si}, \mathrm{O}$ & $\mathrm{Ca}=2$ \\
\hline $6 \mathrm{~d}$ & $\mathrm{Fe}, \mathrm{Si}, \mathrm{O}$ & $\mathrm{Ti}=1.13$ \\
\hline $6 f$ & $\mathrm{Fe}, \mathrm{O}, \mathrm{Si}, \mathrm{K}, \mathrm{Ca}, \mathrm{Ba}, \mathrm{Al}, \mathrm{Ti}, \mathrm{Zn}$ & \\
\hline $7 \mathrm{f}$ & $\mathrm{Si}, \mathrm{Fe}, \mathrm{O}$ & \\
\hline $8 \mathrm{a}$ & $\mathrm{Si}, \mathrm{Fe}, \mathrm{K}, \mathrm{O}, \mathrm{Al}$ & \\
\hline $9 b$ & $\mathrm{Si}, \mathrm{Fe}, \mathrm{O}, \mathrm{Al}$ & \\
\hline $10 \mathrm{~b}$ & $\mathrm{Fe}, \mathrm{Si}, \mathrm{O}, \mathrm{Al}, \mathrm{K}$ & \\
\hline $10 \mathrm{~d}$ & $\mathrm{Fe}, \mathrm{Si}, \mathrm{O}$ & \\
\hline $11 \mathrm{~g}$ & $\mathrm{Fe}, \mathrm{Si}, \mathrm{O}, \mathrm{Ca}$ & \\
\hline $12 \mathrm{c}$ & $\mathrm{Fe}, \mathrm{Cr}, \mathrm{Ni}, \mathrm{O}$ & \\
\hline \multicolumn{3}{|c|}{ CLUSTER 4} \\
\hline 1f & $\mathrm{Si}, \mathrm{Ca}, \mathrm{Fe}, \mathrm{O}$ & $\mathrm{Ca}=45$ \\
\hline $3 g$ & $\mathrm{Ca}, \mathrm{Cl}, \mathrm{S}, \mathrm{O}, \mathrm{Si}, \mathrm{Al}$ & $\mathrm{Si}=21.67$ \\
\hline $5 f$ & $\mathrm{Ca}, \mathrm{Si}, \mathrm{O}, \mathrm{Fe}$ & $\mathrm{O}=11.67$ \\
\hline $6 \mathrm{~h}$ & $\mathrm{Ca}, \mathrm{Si}, \mathrm{O}, \mathrm{Cl}, \mathrm{Al}, \mathrm{K}, \mathrm{S}, \mathrm{Fe}$ & $\mathrm{Fe}=8.67$ \\
\hline $10 \mathrm{c}$ & $\mathrm{Ca}, \mathrm{Si}, \mathrm{O}, \mathrm{Al}, \mathrm{Fe}$ & $\mathrm{Cl}=5$ \\
\hline $11 \mathrm{f}$ & $\mathrm{Ca}, \mathrm{Si}, \mathrm{Fe}, \mathrm{O}$ & $\mathrm{Al}=4.33$ \\
\hline \multicolumn{3}{|c|}{ CLUSTER 5} \\
\hline $2 \mathrm{~d}$ & $\mathrm{Si}, \mathrm{K}, \mathrm{O}$ & $\mathrm{Si}=60$ \\
\hline $3 d$ & $\mathrm{Si}, \mathrm{O}$ & $\mathrm{O}=27.22$ \\
\hline $5 c$ & $\mathrm{Si}, \mathrm{O}$ & $\mathrm{K}=6.78$ \\
\hline $6 a$ & $\mathrm{Si}, \mathrm{O}, \mathrm{Cl}, \mathrm{K}, \mathrm{Ca}, \mathrm{Ba}, \mathrm{Al}, \mathrm{Zn}$ & $\mathrm{Al}=2.55$ \\
\hline $6 b$ & $\mathrm{Si}, \mathrm{O}, \mathrm{K}, \mathrm{Al}, \mathrm{Ca}, \mathrm{Ba}, \mathrm{Na}, \mathrm{Zn}$ & $\mathrm{Ca}=1.11$ \\
\hline $7 \mathrm{a}$ & $\mathrm{Si}, \mathrm{O}, \mathrm{Al}$ & $\mathrm{Ba}=1.11$ \\
\hline $7 \mathrm{e}$ & $\mathrm{Si}, \mathrm{O}, \mathrm{K}$ & \\
\hline $9 \mathrm{c}$ & $\mathrm{Si}, \mathrm{O}$ & \\
\hline $11 \mathrm{e}$ & $\mathrm{Si}, \mathrm{O}$ & \\
\hline
\end{tabular}

The "radon storm" from 2-6 June 1997, was attributed to an advective process during the same period resulting in the transport of air masses from South America to the Antarctic Peninsula. This fact is evident by inspecting the satellite image sequence depicted in Fig. 6. From this point of view, one can assume that the increase in $\mathrm{Si}$ can result from the same atmospheric transport mechanism which was responsible for the increase in ${ }^{222} \mathrm{Rn}$, supporting the hypothesis that the cyclonic systems travelling along the vicinity of the Antarctica boundary may have enough energy to pick up fine resuspended soil dust of equivalent diameters as high as $10-50 \mu \mathrm{m}$ from Patagonia and spread them out to distances over $1000 \mathrm{~km}$ from their origin.

\section{Conclusions}

Insoluble airborne particles found in atmosphere of Chilean Patagonia show a high crustal signal throughout the whole mon- itoring year as indicated by the predominance of several types of aluminosilicates. Contributions from marine and anthropogenic particles are secondary. On the other hand, insoluble airborne particles found in KGI present a high marine influence, having large contributions from sea salt and sulfates. Crustal and anthropogenic particles are predominant during the austral summer; $\mathrm{Si}$ and $\mathrm{C}$ are exceptions and increase during specific atmospheric episodes in winter. Insoluble airborne particles found in snow deposited on KGI demonstrate a significant crustal influence, with a high assortment of morphology and associated mainly with silicates of aluminium, potassium, calcium, magnesium and iron among rare other species containing $\mathrm{Ti}, \mathrm{Ni}$ and $\mathrm{Cr}$. Table 5 summarizes the main contribution in terms of relative abundance of chemical elements for each studied site.

Coarse particles with equivalent diameters of up to $170 \mu \mathrm{m}$ were observed at 23.0-24.1 meq $\mathrm{H}_{2} \mathrm{O}$ depth with composition based on $\mathrm{SiO}_{2}$ (particles with a black texture like tephra when 
Table 3. Cluster analysis for particles deposited on Lange Glacier, elemental composition and abundance

\begin{tabular}{|c|c|c|}
\hline Type & Elemental composition & Average proportion $(>1 \%)$ \\
\hline \multicolumn{3}{|c|}{ CLUSTER 1} \\
\hline $\mathrm{A} 2$ & $\mathrm{Si}, \mathrm{O}, \mathrm{Cl}, \mathrm{Fe}$ & $\mathrm{Si}=40.94$ \\
\hline A3 & $\mathrm{Si}, \mathrm{Cl}, \mathrm{O}, \mathrm{Ti}, \mathrm{Fe}$ & $\mathrm{O}=17.19$ \\
\hline A4 & $\mathrm{Si}, \mathrm{O}, \mathrm{Fe}, \mathrm{Cr}, \mathrm{Ni}$ & $\mathrm{Fe}=12.94$ \\
\hline $\mathrm{C} 1$ & $\mathrm{Si}, \mathrm{O}, \mathrm{Al}, \mathrm{Ca}, \mathrm{Fe}, \mathrm{K}, \mathrm{Ti}$ & $\mathrm{Al}=9.75$ \\
\hline $\mathrm{C} 2$ & $\mathrm{Si}, \mathrm{O}, \mathrm{Al}, \mathrm{S}, \mathrm{Fe}, \mathrm{K}, \mathrm{Ti}$ & $\mathrm{Ca}=5.75$ \\
\hline D3 & $\mathrm{Si}, \mathrm{Ca}, \mathrm{O}, \mathrm{Al}, \mathrm{K}, \mathrm{Fe}, \mathrm{Ti}$ & $\mathrm{K}=4.19$ \\
\hline E1 & $\mathrm{Si}, \mathrm{K}, \mathrm{O}, \mathrm{Al}, \mathrm{Fe}$ & $\mathrm{Cl}=2.94$ \\
\hline $\mathrm{F} 2$ & $\mathrm{Si}, \mathrm{O}, \mathrm{Al}, \mathrm{Cl}, \mathrm{Ti}, \mathrm{Fe}, \mathrm{Mg}, \mathrm{K}$ & $\mathrm{Ti}=2.56$ \\
\hline F6 & $\mathrm{Si}, \mathrm{Al}, \mathrm{O}, \mathrm{Ca}$ & \\
\hline F7 & $\mathrm{Si}, \mathrm{O}, \mathrm{Al}, \mathrm{Fe}, \mathrm{Cl}, \mathrm{S}, \mathrm{Ca}, \mathrm{K}, \mathrm{Ti}, \mathrm{Zn}$ & \\
\hline F8 & $\mathrm{Si}, \mathrm{K}, \mathrm{O}, \mathrm{Al}, \mathrm{Fe}$. & \\
\hline F9 & $\mathrm{Si}, \mathrm{Ca}, \mathrm{O}, \mathrm{Al}, \mathrm{Fe}$ & \\
\hline G1 & $\mathrm{Si}, \mathrm{O}, \mathrm{Al}$ & \\
\hline $\mathrm{H} 4$ & $\mathrm{Si}, \mathrm{O}, \mathrm{Fe}, \mathrm{Al}, \mathrm{Ca}, \mathrm{Ti}$ & \\
\hline H5 & $\mathrm{Si}, \mathrm{Fe}, \mathrm{O}$ & \\
\hline H9 & $\mathrm{Si}, \mathrm{Ca}, \mathrm{O}, \mathrm{Fe}, \mathrm{Mg}, \mathrm{Al}, \mathrm{K}, \mathrm{Ti}$ & \\
\hline \multicolumn{3}{|c|}{ CLUSTER 2} \\
\hline D2 & $\mathrm{Fe}, \mathrm{Cr}, \mathrm{O}, \mathrm{Si}, \mathrm{Ni}$ & $\mathrm{Fe}=63$ \\
\hline E4 & $\mathrm{Fe}, \mathrm{Cr}, \mathrm{O}, \mathrm{Si}, \mathrm{Ni}$ & $\mathrm{Cr}=16$ \\
\hline G4 & $\mathrm{Fe}, \mathrm{O}$ & $\mathrm{O}=12$ \\
\hline H6 & $\mathrm{Fe}, \mathrm{O}, \mathrm{S}, \mathrm{Ni}, \mathrm{P}, \mathrm{Cl}$ & $\mathrm{Ni}=5$ \\
\hline \multirow[t]{2}{*}{ H8 } & $\mathrm{Fe}, \mathrm{Cr}, \mathrm{Ni}, \mathrm{O}$ & $\mathrm{Si}=2$ \\
\hline & & $\mathrm{S}=1$ \\
\hline \multicolumn{3}{|c|}{ CLUSTER 3} \\
\hline A1 & $\mathrm{Cl}, \mathrm{Si}, \mathrm{Ti}, \mathrm{S}, \mathrm{K}, \mathrm{O}, \mathrm{Ca}$ & $\mathrm{S}=24.5$ \\
\hline B2 & $\mathrm{Si}, \mathrm{S}, \mathrm{Cl}, \mathrm{O}$ & $\mathrm{Cl}=21.6$ \\
\hline $\mathrm{C} 4$ & $\mathrm{~S}, \mathrm{O}, \mathrm{Si}, \mathrm{Cl}, \mathrm{C}$ & $\mathrm{Si}=19.5$ \\
\hline E2 & $\mathrm{Si}, \mathrm{S}, \mathrm{O}, \mathrm{Cl}, \mathrm{Fe}, \mathrm{Ti}$ & $\mathrm{O}=18.5$ \\
\hline F5 & $\mathrm{Si}, \mathrm{S}, \mathrm{Cl}, \mathrm{O}$ & $\mathrm{Ca}=4.7$ \\
\hline F10 & $\mathrm{Cl}, \mathrm{O}$ & $\mathrm{Fe}=4$ \\
\hline F11 & $\mathrm{S}, \mathrm{O}, \mathrm{Si}$ & $\mathrm{Ti}=2.9$ \\
\hline G5 & $\mathrm{Ca}, \mathrm{Cl}, \mathrm{S}, \mathrm{O}, \mathrm{Al}, \mathrm{Zn}$ & $\mathrm{Al}=1.3$ \\
\hline $\mathrm{H} 2$ & $\mathrm{~S}, \mathrm{Si}, \mathrm{O}, \mathrm{C}, \mathrm{Fe}, \mathrm{Ti}, \mathrm{P}, \mathrm{Al}, \mathrm{Cl}, \mathrm{Ca}$ & $\mathrm{C}=1.2$ \\
\hline $\mathrm{H} 3$ & $\mathrm{~S}, \mathrm{Fe}, \mathrm{O}, \mathrm{Si}, \mathrm{Cl}, \mathrm{C}, \mathrm{Al}$ & $\mathrm{K}=1$ \\
\hline \multicolumn{3}{|c|}{ CLUSTER 4} \\
\hline B1 & $\mathrm{Si}, \mathrm{O}$ & $\mathrm{Si}=64.44$ \\
\hline $\mathrm{C} 3$ & $\mathrm{Si}, \mathrm{O}, \mathrm{Mg}$ & $\mathrm{O}=28.33$ \\
\hline D1 & $\mathrm{Si}, \mathrm{O}$ & $\mathrm{K}=3.11$ \\
\hline E3 & $\mathrm{Si}, \mathrm{O}$ & $\mathrm{Mg}=1.67$ \\
\hline F3 & $\mathrm{Si}, \mathrm{O}$ & $\mathrm{Ca}=1.33$ \\
\hline $\mathrm{F} 4$ & $\mathrm{Si}, \mathrm{O}, \mathrm{K}$ & $\mathrm{Al}=1.11$ \\
\hline G3 & $\mathrm{Si}, \mathrm{O}$ & \\
\hline H7 & $\mathrm{Si}, \mathrm{Ca}, \mathrm{O}, \mathrm{Al}, \mathrm{K}$ & \\
\hline H10 & $\mathrm{Si}, \mathrm{O}$ & \\
\hline \multicolumn{3}{|c|}{ CLUSTER 5} \\
\hline F1 & $\mathrm{Al}, \mathrm{O}$ & $\mathrm{Al}=55$ \\
\hline $\mathrm{G} 2$ & $\mathrm{Al}, \mathrm{S}, \mathrm{O}, \mathrm{Si}$ & $\mathrm{S}=23.33$ \\
\hline \multirow[t]{2}{*}{$\mathrm{H} 1$} & $\mathrm{~S}, \mathrm{Al}, \mathrm{O}, \mathrm{Si}$ & $\mathrm{O}=15$ \\
\hline & & $\mathrm{Si}=6.67$ \\
\hline
\end{tabular}




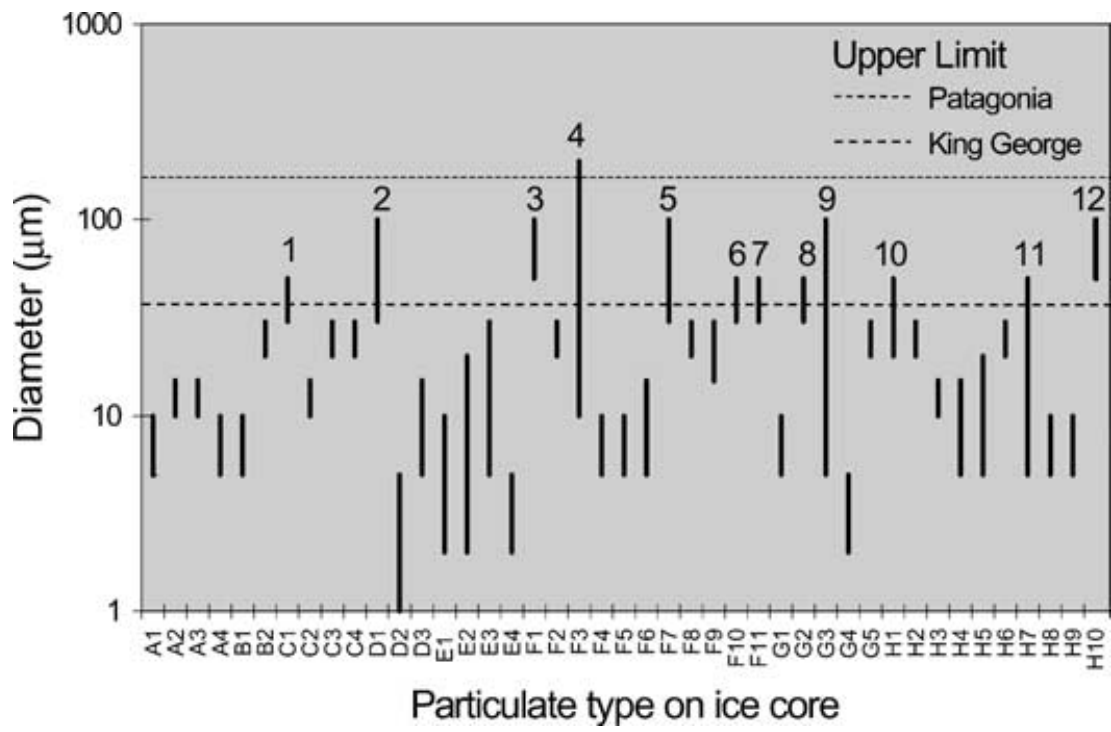

Fig 3. Range of diameters of insoluble particles found in the Lange ice core. Dashed lines indicate Patagonian and King George Island upper limits.

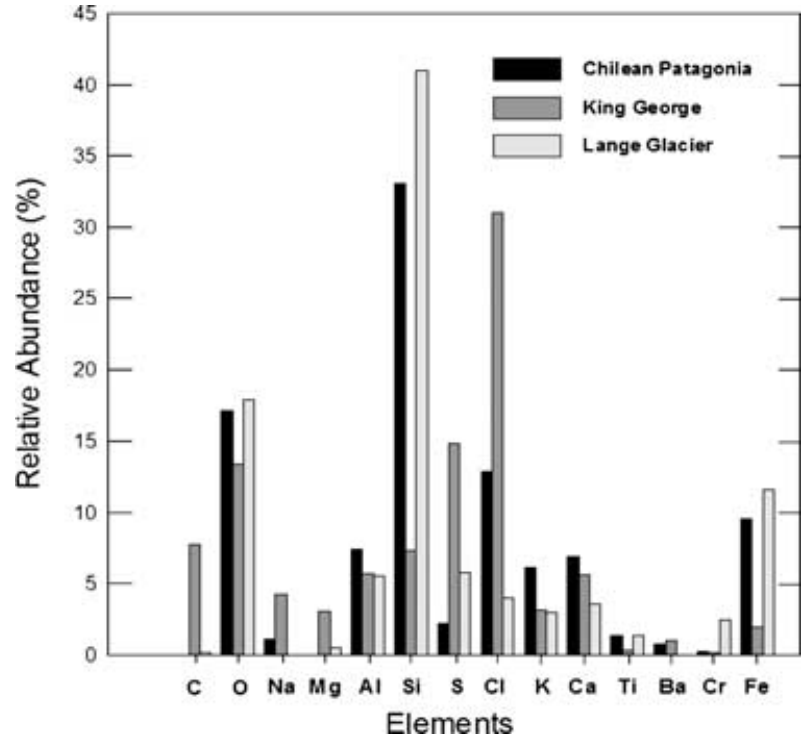

Fig 4. Relative abundance of insoluble particles in the Lange Glacier ice core and air at King George Island and Chilean Patagonia. observed under an optical microscope). It is probable that the presence of these particles could not be linked to long-range atmospheric transport processes. Furthermore, similar large diameters were not found in the KGI atmosphere during a year of continuous monitoring. These particles also occurred in association with groups of particles of diameter larger than $30 \mu \mathrm{m}$ and exhibiting high concentrations of $\mathrm{Al}, \mathrm{S}$ and $\mathrm{Si}$. A possible source of these particles is the vulcanism in the South Shetlands Archipelago, mainly in Deception Island.

The higher Pearson correlation coefficient among the most abundant chemical elements in Chilean Patagonia, the KGI atmosphere, snow, firn and ice samples indicates a high similarity in composition between insoluble coarse-mode particles in the Patagonian atmosphere and in the snow in the Antarctic Islands. Individual particle analysis revealed a clear insight into the maintenance of an effective transport pathway of mineral aerosols from Patagonia to West Antarctica. The atmospheric mechanism most likely to be responsible for this transport is the cyclonic system which influences a region as large as part of Patagonia and the Antarctic Peninsula. Acquisition of satellite image sequences for these systems simultaneously with

Table 4. Vertical distribution of elemental abundance for snow, firn and ice layers of the Lange Glacier

\begin{tabular}{|c|c|c|c|c|c|c|c|c|c|c|c|c|c|c|c|}
\hline \multirow[b]{2}{*}{ meqH $_{2} \mathrm{O}$} & \multicolumn{15}{|c|}{ Relative elemental abundance (\%) in Lange ice core } \\
\hline & $\mathrm{C}$ & $\mathrm{O}$ & $\mathrm{P}$ & $\mathrm{Mg}$ & $\mathrm{Al}$ & $\mathrm{Si}$ & $\mathrm{S}$ & $\mathrm{Cl}$ & K & $\mathrm{Ca}$ & $\mathrm{Ti}$ & $\mathrm{Cr}$ & $\mathrm{Fe}$ & $\mathrm{Ni}$ & $\mathrm{Zn}$ \\
\hline $0.5-1.04$ & 0 & 16 & 0 & 0 & 0 & 49.5 & 5.25 & 11.5 & 1.5 & 0.75 & 3 & 2 & 6.25 & 2 & 0 \\
\hline $3.87-4.34$ & 0.4 & 19 & 0 & 3 & 8.25 & 49.75 & 13.5 & 1.6 & 2.55 & 1.5 & 1.65 & 0 & 5.55 & 0 & 0 \\
\hline $7.25-8.25$ & 0 & 9.4 & 0 & 0 & 5.5 & 32.25 & 0 & 0 & 5.5 & 6.6 & 1.65 & 9 & 20.5 & 1.5 & 0 \\
\hline $13.85-14.84$ & 0 & 19.75 & 0 & 0 & 6 & 39.25 & 3 & 2.25 & 8 & 0 & 1.5 & 3 & 13.25 & 0.5 & 0 \\
\hline $23.0-24.01$ & 0 & 22.75 & 0 & 0.3 & 11.3 & 43.25 & 4 & 6.2 & 2.85 & 4 & 1.2 & 0 & 3.95 & 0 & 0.2 \\
\hline $26.01-26.98$ & 0 & 23 & 0 & 0 & 9.5 & 37 & 7.5 & 6 & 0 & 8 & 0 & 0 & 8 & 0 & 1 \\
\hline $30.7-31.25$ & 0.5 & 15.75 & 0.3 & 0.5 & 5.2 & 36 & 7.25 & 0.75 & 0.5 & 4.3 & 0.6 & 3 & 23.6 & 1.75 & 0 \\
\hline Average & 0.13 & 17.95 & 0.043 & 0.54 & 5.54 & 41 & 5.79 & 4.04 & 2.99 & 3.59 & 1.37 & 2.43 & 11.59 & 0.82 & 0.17 \\
\hline
\end{tabular}




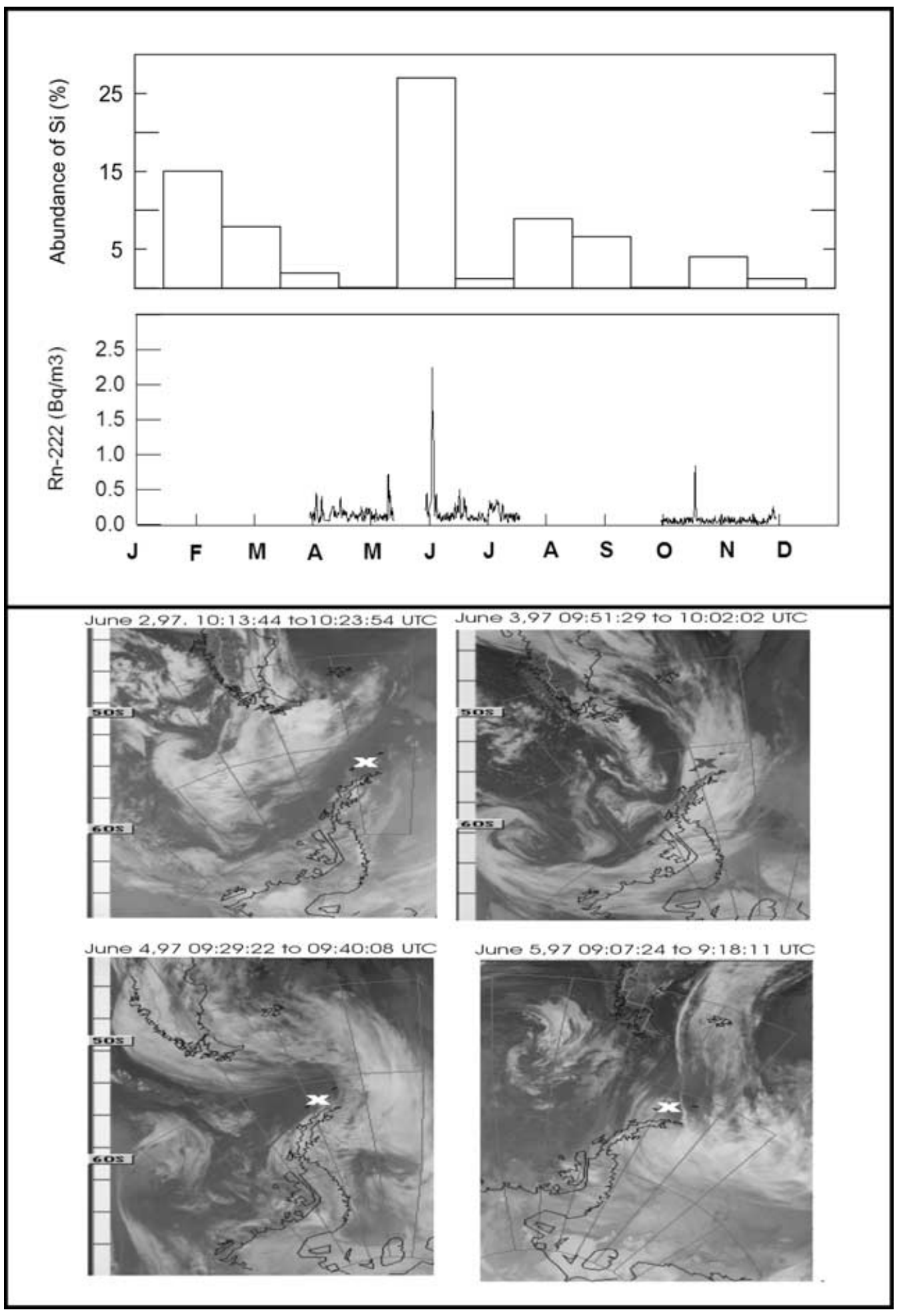

Fig 5. Annual variation in $\mathrm{Si}$ abundance over atmospheric aerosols and ${ }^{222} \mathrm{Rn}$ monitoring (upper part). Sequence of 12 NOAA satellite images, channels 3 and 4 (lower part), showing the dynamic of a cyclonic system over the Antarctic Peninsula during 2-5 June 1997. X marks the location of King George Island. 
Table 5. Relative elemental abundances, diameters and probable origin for airborne particles

\begin{tabular}{|c|c|c|c|c|}
\hline Site & Abundance (\%) & Diameter $(\mu \mathrm{m})$ & Main elements & Probable origin \\
\hline \multirow[t]{5}{*}{ King George Island } & 29 & $2-15$ & $\mathrm{~S}, \mathrm{O}, \mathrm{Ca}$ & Marine \\
\hline & 26 & $5-30$ & $\mathrm{Cl}, \mathrm{Na}$ & Marine \\
\hline & 19 & $2-20$ & $\mathrm{Cl}, \mathrm{O}, \mathrm{Al}, \mathrm{Fe}$ & Marine/crustal \\
\hline & 17 & $5-40$ & $\mathrm{Si}, \mathrm{O}$ & Crustal (quartz) \\
\hline & 9 & $2-15$ & $\mathrm{C}, \mathrm{Al}$ & Anthropogenic/crustal \\
\hline \multirow[t]{5}{*}{ Patagonia } & 46 & $5-120$ & $\mathrm{Si}, \mathrm{O}, \mathrm{Al}$ & Crustal \\
\hline & 19 & $2-25$ & $\mathrm{Fe}, \mathrm{Si}, \mathrm{O}, \mathrm{Al}$ & Crustal \\
\hline & 16 & $2-140$ & $\mathrm{Cl}, \mathrm{Si}, \mathrm{O}, \mathrm{S}, \mathrm{Na}$ & Marine/crustal \\
\hline & 11 & $5-40$ & $\mathrm{Si}, \mathrm{O}, \mathrm{K}$ & Crustal \\
\hline & 8 & $10-15$ & $\mathrm{Ca}, \mathrm{Si}, \mathrm{O}, \mathrm{Fe}$ & Marine/crustal \\
\hline \multirow[t]{5}{*}{ Lange Glacier } & 37 & $2-40$ & $\mathrm{Si}, \mathrm{O}, \mathrm{Fe}$ & Crustal \\
\hline & 23 & $5-50$ & $\mathrm{~S}, \mathrm{Cl}, \mathrm{Si}, \mathrm{O}$ & Marine \\
\hline & 21 & $5-170$ & $\mathrm{Si}, \mathrm{O}$ & Crustal (quartz) \\
\hline & 12 & $2-20$ & $\mathrm{Fe}, \mathrm{Cr}, \mathrm{O}, \mathrm{Ni}$ & Crustal \\
\hline & 7 & $20-80$ & $\mathrm{Al}, \mathrm{S}, \mathrm{O}$ & Crustal/marine \\
\hline
\end{tabular}

continuous monitoring of atmospheric ${ }^{222} \mathrm{Rn}$ and $\mathrm{Si}$ represents a very broad approach to the identification of tropospheric transport process to Antarctica.

\section{Acknowledgments}

We thank the Brazilian Antarctic Programme (PROANTAR) and the Brazilian National Council for Scientific and Technological Development $(\mathrm{CNPq})$ for financial and logistical support in Antarctica. We also thank the technical-scientific staff of the Atmospheric Aerosols and Radioactivity Project from the National Institute for Space Research (INPE) for sampling in Antarctica during the winter and summer seasons. We dedicate this study to Fátima from PUC-RJ, in memoriam.

\section{References}

Artaxo, P., Andrade, F. and Van Grieken, R. 1990. Elemental composition of aerosols sampled in the Brazilian Antarctic station, analysed by PIXE, EPMA and absolute principal factor analysis. Proceedings of the Second International Environmental Chemistry Congress, São Paulo, Brazil.

Balkanski, Y. J. and Jacob, D. J. 1990. Transport of continental air to the sub-Antarctic Indian Ocean. Tellus 42B, 62-75.

Basile, I., Grousset, F. E., Revel, M., Petit, J. R., Biscaye, P. E., et al 1997. Patagonian origin of glacial dust deposited in East Antarctica (Vostok and Dome C) during Glacial Stages 2. 4 and 6. Earth Planet. Sci. Lett. 146, 573-589.

Brian, M., Royer, A., Petit, R. and Lorius, C. 1982. Late glacial input of aeolian continental dust in the Dome $\mathrm{C}$ ice core: additional evidence from individual microparticle analysis. Ann. Glaciol. 3, 27-30.

Chiminello, F., Mittner, P., Campello, A. and Ceccato, D. 2000. Synoptic scale air mass trajectories and aerosol composition at Terra Nova Bay: preliminary analysis. Proceedings of the $8^{\text {th }}$ Workshop of the Italian Research on Antarctic Atmosphere, Editrice Compositori, Bolonha, Italia. 69, 75-82.
Correia, A. L. 1998. Atmospheric Antarctic aerosols: seasonality, elemental composition and relation to "El Niño" (Aerossóis Atmosféricos na Antártica: Sazonalidade, Composição Elementar e Relação com “El Niño”). Thesis, Instituto de Física da Universidade de São Paulo, Brazil.

Dias da Cunha, K., Evangelista, H., Dalia, K. C., Simões, J. and Barros Leite, C. V. 2004. Application of 252 Cf-PDMS to characterize airborne particles deposited in an Antartic glacier. Science of the Total Environment 323, 123-135.

Evangelista, H. 1998. The use of radon on the characterization of transport phenomena and atmospheric environmental impacts at King George Island/Antarctic (O Emprego do Radônio na Caracterização de Fenômenos de Transporte e Impacto Ambiental Atmosféricos na Ilha Rei George/Antártica). Thesis. Instituto de Biologia Roberto Alcântara Gomes da Universidade do Estado do Rio de Janeiro, Brazil.

Evangelista, H. and Pereira, E. B. 2002. Radon flux at King George Island - Antarctic Peninsula. 2002. J. Environ. Radioactivity 61, 283-304.

Iriondo, M. 2000. Patagonian dust in Antarctica. Quaternary Int. 68-71, 83-86.

Jacob, D. J., Prather, M. J., Rasch, P. J., Shia, R., Balkanski, Y. J., et al 1997. Evaluation and intercomparison of global atmospheric transport models using ${ }^{222} \mathrm{Rn}$ and other short-lived tracers. J. Geophys. Res. 102,D5, 5953-5970.

Lambert, G., Polian, G. and Taupin, D. 1970. Existence of periodicity in radon concentrations and in the large-scale circulation at latitudes between $40^{\circ}$ and $70^{\circ}$ South. J. Geophys. Res. 75, 2341-2345.

Lambert, G., Ardouin, B. and Sanak, J. 1990. Atmospheric transport of trace elements toward Antarctica. Tellus 42B, 76-82.

Murphey, B. B. and Hogan, A. W. 1992. Meteorological transport of continental soot to Antarctica? J. Geophys. Res. 19, 33-36.

Petit, J. R., Ezat, U., Barkov, N. I. and Petrov, V. N. 1983. Identification of quartz microparticles in 20,000 BP Antarctic ice samples: a signature of last glacial environment. Scanning Electron Microsc. 4, 1627-1633.

Pereira, E. B. and Evangelista, H. E. 1989. Atmospheric radon measurements by electrostatic precipitation. Nucl. Instrum. Methods A280, 503-505. 
Pereira, E. B. 1990. Radon-222 Time series measurements in the Antarctic Peninsula (1986-1987). Tellus 42B, 39-45.

Polian, G., Lambert, G., Ardouin, B. and Jegou, A. 1986. Long-range transport of continental radon in sub-Antarctic and Antarctic areas. Tellus 38B, 178-189.

Sanak, J. 1989. Radon-222 as an atmospheric tracer. Isotopes of noble gases as tracers in environmental studies. Proceedings of a Consultants' Meeting, IAEA Publications, Vienna, Austria, 241-248.
Schumann, G. 1972. Radon isotopes and daughters in the atmosphere. Arch. Meteorol. Geophys. Bioklimatol. Ser. A21, 149-170.

Simões, J. C., Bremer. U. F., Aquino, F. E. and Ferron, F. A. 1999. Morphology and variations of glacial drainage basins in the King George Island ice field. Antarctica. Ann. Glaciol. 29, 220-224.

Wolff, E. W. and Cachier, H. 1998. Concentrations and seasonal cycle of black carbon in aerosol at a coastal Antactic station. J. Geophys. Res. 103, D9, 11033-11041. 